\title{
Characterizing Western Juniper Expansion via a Fusion of Landsat 5 Thematic Mapper and Lidar Data
}

\author{
Temuulen Tsagaan Sankey, ${ }^{1}$ Nancy Glenn, ${ }^{2}$ Sara Ehinger, ${ }^{3}$ Alex Boebm, ${ }^{4}$ and Stuart Hardegree ${ }^{5}$
}

Authors are ${ }^{1}$ Research Assistant Professor, ${ }^{2}$ Research Associate Professor, and ${ }^{3}$ Graduate Research Assistant, Boise Center Aerospace Laboratory, Idaho State University, 322 East Front Street, Boise, ID 83712, USA; and ${ }^{4}$ Research Technician and ${ }^{5}$ Research Plant Scientist, US Department of AgricultureAgricultural Research Service-Northwest Watershed Research Center, 800 Park Boulevard, Suite 105, Boise, ID 83712, USA.

\begin{abstract}
Juniper encroachment into shrub steppe and grassland systems is one of the most prominent changes occurring in rangelands of western North America. Most studies on juniper change are conducted over small areas, although encroachment is occurring across large regions. Development of image-based methods to assess juniper encroachment over large areas would facilitate rapid monitoring and identification of priority areas for juniper management. In this study, we fused Landsat 5 Thematic Mapper and Light Detection and Ranging (lidar)-based juniper classifications to evaluate juniper expansion patterns in the Reynolds Creek Experimental Watershed of southwestern Idaho. Lidar applications for characterizing juniper encroachment attributes at finer scales were also explored. The fusion-based juniper classification model performed well $(83 \%$ overall accuracy). A comparison of the resulting juniper presence/absence map to a 1965 vegetation cover map indicated $85 \%$ juniper expansion, which was consistent with tree-ring data. Comparisons of current and previous canopy-cover estimates also indicated an increase in juniper density within the historically mapped juniper distribution. Percent canopy cover of juniper varied significantly with land-cover types highlighting areas where intensive juniper management might be prioritized.
\end{abstract}

\section{Resumen}

El avance del Juniperus sobre las estepas arbustivas y los ecosistemas graminosos es uno de los cambios más prominentes ocurriendo actualmente en pastizales del Oeste de América del Norte. La mayoría de los estudios sobre cambios asociados al Juniperus se conducen en áreas pequeñas a pesar de que la invasión de esta especie está ocurriendo a escala de grandes regiones. El desarrollo de métodos basados en imágenes para relevar el avance del Juniperus a escala de áreas extensas facilitaría el monitoreo expeditivo y la identificación de áreas de manejo de Juniperus. En este ensayo fusionamos clasificaciones de Juniperus de imágenes Landsat 5 TM y LIDAR para evaluar los patrones de expansión del Juniperus en la cuenca experimental de Reynolds Creek del sudoeste de Idaho. Aplicaciones del LIDAR para caracterizar atributos de la invasión de Juniperus a escalas más finas también fueron exploradas. El modelo basado en la fusión de la clasificación de Juniperus tuvo un buen desempeño ( $83 \%$ de exactitud general). Una comparación del mapa de presencia/ausencia de Juniperus obtenido con este análisis con un mapa de cobertura de vegetación de 1965 indicó un 85\% de expansión de Juniperus, patrón que fue consistente con datos de anillos de crecimiento de los árboles. La comparación de estimaciones de cobertura de canopeo actuales y pasadas también indicó un aumento en la densidad de Juniperus dentro del área de distribución histórica de Juniperus mapeada. El porcentaje de cobertura del canopeo de Juniperus varió significativamente con el tipo de cobertura del terreno remarcando áreas en las que el manejo intensivo del Juniperus podría ser priorizada.

Key Words: Juniperus occidentalis, land-cover type, tree-ring analysis

\section{INTRODUCTION}

Juniper encroachment is one of the most extensive changes currently occurring in rangelands of the western United States. The spatial extent of juniper species distribution is documented to have increased by an order of magnitude since the mid-19th century throughout the Great Basin (Romme et al. 2009). Reported increases in areal extent have ranged between 30\% and $625 \%$ (Romme et al. 2009), and encroachment rates have

Research was funded by the National Oceanic and Atmospheric Administration Earth System Research Laboratory Physical Sciences Division Grant NA050AR4601137 and the Bureau of Land Management Owyhee Uplands Pilot Project (ISU-BLM Agreement DLA060249).

Correspondence: Temuulen Tsagaan Sankey, Boise Center Aerospace Laboratory, Idaho State University, 322 East Front Street, Boise, ID 83712, USA. Email: sankteki@isu.edu

Manuscript received 30 November 2009; manuscript accepted 22 April 2010. varied between $0.4 \%$ and $4.5 \%$ per year (Sankey and Germino 2008). Intensive land treatments, including prescribed burning and cutting, are now regularly performed to reduce juniper cover where the encroachment is perceived to decrease rangeland forage and deteriorate wildlife habitat for species such as sage grouse.

As juniper trees mature and canopies close in encroached areas, understory vegetation cover decreases, resulting in soil exposure and potential erosion (Tausch et al. 1981; Waichler et al. 2001). The effects of encroaching junipers have been documented to vary because of land-cover types (Miller and Wigand 1994). Increasing juniper cover might have no significant effect on low sagebrush cover in encroached areas, whereas it can drastically reduce mountain big sagebrush and herbaceous cover (Miller et al. 2000). Similarly, juniper cover and density can vary in encroached areas because of land-cover 
types (Miller et al. 2000). This might indicate that junipers can reach critical transitional points, such as irreversible woodland stage, at varying times because of land-cover types. Efficient methods for characterization of juniper encroachment rates as a function of land-cover types across large areas are needed to guide regional policy and identify priority areas for intensive management.

Most evidence for juniper encroachment has been provided by dendrochronological, demographic, or photographic studies (Sankey and Germino 2008). These methods provide detailed and accurate records of stand history and development, but generally cover a relatively small spatial extent (Romme et al. 2009). Sankey and Germino (2008) demonstrated the utility of moderate-resolution Landsat 5 Thematic Mapper (TM) satellite imagery and spectral mixture analysis in assessing juniper encroachment over large areas. This study aims to improve upon the previous methodology by fusing Landsat 5 TM imagery with Light Detection and Ranging (lidar) data. This study also explores the utility of lidar data for characterizing juniper encroachment attributes at finer scales ( $<30$-m pixels).

Pixels in Landsat 5 TM imagery are $900 \mathrm{~m}^{2}(30 \times 30 \mathrm{~m})$ in size, and thus often include a mixture of vegetation cover types. This is particularly evident in woodlands and juniperencroached rangelands, where juniper trees are dispersed among herbaceous and sagebrush cover types. The mixture of cover types within pixels poses a fundamental challenge in classifying pixels, because the spectral characteristics of the mixed pixels do not represent any single land-cover type (Lillesand and Kiefer 2000). Spectral mixture analysis techniques have been developed to estimate the relative proportions of a given pixel that comprise different land-cover types (Adams et al. 1986; Small 2004; Xiao and Moody 2005). These techniques have been successfully used to estimate tree abundance within pixels (Chen et al. 2004; Small and Lu 2006). Sankey and Germino (2008) have also used a linear spectral unmixing technique to detect the presence of sparsely distributed juniper within pixels by first estimating subpixel juniper percent cover and then producing a binary map of juniper presence and absence.

Lidar data, which have been most commonly used in forestry applications, are now increasingly used for vegetation classification of semiarid rangelands (Weltz et al. 1994; Ritchie et al. 1995; Rango et al. 2000; Mundt et al. 2006; Streutker and Glenn 2006; Bork and Su 2007; Riaño et al. 2007; Su and Bork 2007). Lidar applications have not been explored in juniper encroachment studies. Lidar data are potentially well suited to distinguish sparsely distributed individual trees from lowerstatured background vegetation. In this study, we use vegetation-height data derived from lidar point cloud data to compliment the spectral information from Landsat 5 TM to improve juniper classification and to evaluate changes in juniper density and extent over time. Following Sankey et al. (2006), we separately examine two different processes of western juniper (Juniperus occidentalis Hook) encroachment in southwestern Idaho by comparing current and historic juniper distribution maps: 1) infill or tree density increase within the existing woodlands that were previously mapped in 1965, and 2) expansion or establishment of new juniper trees in former grasslands or shrublands mapped in 1965 . We also explore
Table 1. Study area characteristics at the Reynolds Creek Experimental Watershed.

\begin{tabular}{ccc}
\hline Study areas & Aerial extent in 1965 (ha) & Aerial extent in 2008 (ha) \\
\hline 1 & 4.5 & 85 \\
2 & 5.9 & 86 \\
3 & 14.1 & 79 \\
Total & 24.5 & 250 \\
\hline
\end{tabular}

how the rates at which these processes occur might differ due to land-cover types.

\section{METHODS}

\section{Study-Site Description}

The 239- $\mathrm{km}^{2}$ Reynolds Creek Experimental Watershed (RCEW) was established in 1960 as an outdoor laboratory for hydrologic and natural resources research (Slaughter et al. 2001). Detailed information on watershed geography, vegetation, soils, hydrology, and weather at the watershed can be obtained from previously published references (Hanson 2001; Hanson et al. 2001; Marks et al. 2001; Pierson et al. 2001; Seyfried et al. 2001a, 2001b, 2001c, 2001d). Within the RCEW, this study focuses on three small areas of historic western juniper distribution. The current areal extent of the three study areas was determined by defining a larger area around each of the western juniper stands documented in 1965 (Table 1).

\section{Field Methods}

Field work was completed during the months of July and August 2009 to corroborate image-based juniper change detection. Prior to field work, a total of 100 random points were generated within the three study areas with the use of Hawth's tools in ESRI $^{\circledR}$ ArcMap $^{\text {TM }} 9.3$ software (Environmental Systems Research Institute, Inc., Redlands, CA). A $30 \times 30$ m (Landsat 5 TM) pixel at each of these random points was selected and the coordinates of the four corners of each pixel determined from the imagery. We established field plots by navigating with a Trimble GeoXT global positioning system receiver (submeter postprocessing horizontal accuracy) to the four corners of the corresponding $30 \times 30$ area on the ground. Within each $30 \times 30 \mathrm{~m}$ field plot, every juniper stem was mapped, measured for height and basal diameter, and classified as either mature tree $(>8 \mathrm{~cm}$ in diameter at $30-\mathrm{cm}$ height $)$ or seedling $(<8 \mathrm{~cm}$ in diameter at $30-\mathrm{cm}$ height). Canopy width of individual trees was measured and percent canopy cover was estimated by adding canopy area measurements of all trees in the plot. All mature trees in the first 25 plots were cored at $30-\mathrm{cm}$ height with an increment borer to estimate age (trees in the remaining plots were not cored because of time constraints). A total of 35 randomly selected seedlings were destructively sampled at ground height and $30-\mathrm{cm}$ height to determine seedling age and to estimate an age-correction factor for older trees that were only sampled at 30-cm height.

\section{Tree-Age Estimate}

The core samples were processed and dated with the use of standard dendrochronological methods (Stokes and Smiley 
1968). Only the samples that contained pith or samples that were geometrically estimated to have pith within five missing rings were selected for age estimates. A total of 206 core samples $(\sim 90 \%$ of all samples) were dated successfully. All seedling samples were successfully dated with the use of crosssection disks from the base of the stem and $30 \mathrm{~cm}$ above ground. The mean difference in the number of rings counted at the base of the stems and $30 \mathrm{~cm}$ above ground was $10 \mathrm{yr}$, which was added to the mature tree-age estimates to adjust for coring height. The estimated tree age was then examined with tree height (measured in the field) with the use of a simple linear regression. This relationship was used to determine whether it was reasonable to infer tree ages from lidar-derived juniper height estimates over large areas beyond the field plots.

\section{Image Sources and Juniper Classification}

Digital juniper maps from two different years were used: 1965 and 2008. The 1965 juniper map was generated from a 1965 vegetation cover type map provided by the US Department of Agriculture-Agricultural Research Service Northwest Watershed Research Center (ARS NWRC) in a digitized, georeferenced shapefile format. The 1965 map was originally generated with the use of a combination of field survey and aerial photographs (1:12000 scale) between 1963 and 1965. This map included 987 polygons with a minimum mapping unit of $\sim 15 \mathrm{~m}^{2}$. Four of the polygons had juniper mapped as a predominant species and were selected to generate a 1965 juniper map in a shapefile. Two of the 1965 polygons were adjacent to each other and were, therefore, combined into one polygon. The map was then converted into a raster format with $30 \times 30 \mathrm{~m}$ pixels to generate a 1965 juniper presence/absence map of the three study areas (Table 1).

The 2008 juniper map was generated from a fusion of a multitemporal composite of summer- and fall-season Landsat 5 TM satellite images $(30 \times 30 \mathrm{~m}$ pixels $)$ and airborne lidar data. The Landsat 5 TM images and lidar point cloud data were first individually classified to produce a binary juniper presence/ absence map and then fused to produce a final juniper presence/ absence map. The Landsat 5 TM multitemporal composite consisted of two images (Path 42 and Row 30) acquired on 9 July 2008 and 29 October 2008. Both images were 1) corrected for atmospheric effects with the use of the FLAASH module in ENVI software (ENVI Version 4.5; ITT Industries Inc., Boulder, CO), 2) projected in Universal Transverse Mercator Zone 11N, North American Datum 1983 projection and datum, 3) georectified and coregistered (all root-mean-square errors $<7 \mathrm{~m}$ ), and 4) subset to the study areas. Then, the summer image bands $2(0.52-0.60 \mu \mathrm{m}), 3(0.63-0.69 \mu \mathrm{m}), 4$ $(0.76-0.90 \mu \mathrm{m})$, and $5(1.55-1.75 \mu \mathrm{m})$ were spectrally subset and stacked with the fall image bands 2,3 , and 4 to generate the multitemporal composite. This combination of bands and dates was used to separate evergreen junipers from the background sagebrush-herbaceous vegetation mix, by taking advantage of the spectral reflectance changes in the fall due to the senescent herbaceous vegetation and lower greenness of the shrubs in the fall compared to the summer. Furthermore, the multitemporal stacking increased the number of relevant bands available for the spectral unmixing (see Singh and Glenn 2009). Based on preliminary data exploration, we determined that the
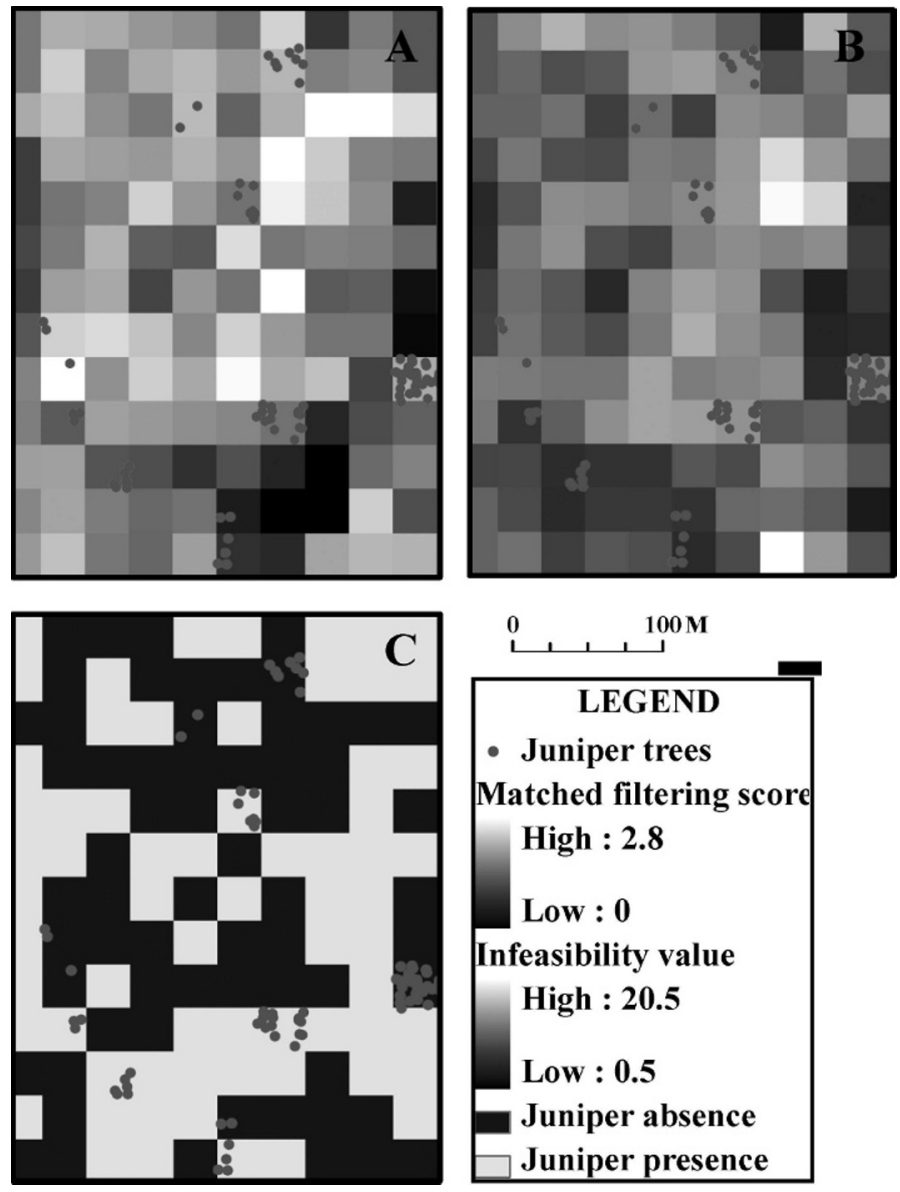

Figure 1. Landsat 5 Thematic Mapper (TM) image classification. The Landsat 5 TM image composite was classified with the use of the mixture tuned matched filtering (MTMF), which is a spectral mixture analysis technique that estimates subpixel abundance of a target cover type. The MTMF technique produced two images that were used together to classify juniper trees (circles): 1) matched filtering scores (A) that estimate the abundance of juniper within each pixel, and 2) infeasibility values (B), which represent the likelihood of false positives in the matched filtering scores. The two images were combined to generate a binary juniper presence/absence map (C).

selected bands (bands 2-5) provided the most spectral separability. The composite image was classified with the use of the mixture tuned matched filtering (MTMF) technique (Boardman 1998) in ENVI software. MTMF is a spectral mixture analysis technique that estimates subpixel abundance of a target cover type, in this case, juniper (see Mitchell and Glenn 2009 for details on MTMF technique). With the use of a digital color aerial orthophotograph with a 1-m resolution (US Department of Agriculture National Agricultural Program Imagery 2009) and our knowledge of the area, we selected 10 pure pixels in the Landsat 5 TM image composite with the greatest juniper canopy percent cover (approximately 85-90\% canopy cover) as training pixels. The MTMF technique produces two images that can be used together to classify juniper: 1) matched filtering scores (Fig. 1A) that estimate the abundance of juniper within each pixel, and 2) infeasibility values (Fig. 1B), which represent the likelihood of false positives in the matched filtering scores. The two images were combined to generate a binary juniper presence/absence map 


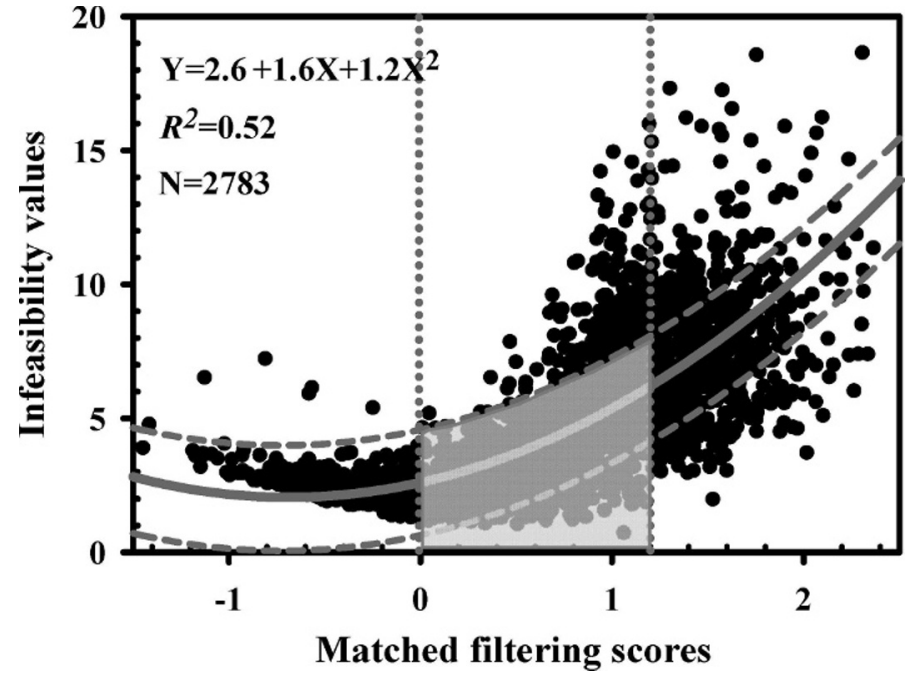

Figure 2. Juniper presence and absence classification of 2008 Landsat 5 Thematic Mapper multitemporal composite with the use of the mixture tuned matched filtering (MTMF) technique with a regression approach. The quadratic regression model was fitted to the MTMF-produced matched filtering scores and infeasibility values $\left(R^{2}=0.52, P<0.0001\right)$. Pixels that fell under one positive standard deviation (upper dashed gray line) above the regression curve (solid gray line) that had matched filtering scores of $0-1.2$ (dotted gray lines) were classified as juniper presence (pixels highlighted in gray). All other pixels were classified as juniper absence.

(Fig. 1C). To determine the best approach to combining the two bands, pixels from the three study areas were extracted from the image, and the relationship between the two bands was examined using scatter plots and several regression approaches. The following quadratic polynomial regression model (Equation 1) was then chosen using a statistical software (SPSS 15.0 for Windows; SPSS, Chicago, IL):

$$
Y=2.604+1.603 X+1.164 X^{2}
$$

where the infeasibility values were the response variable and the matched filtering scores and a quadratic term were the predictor variables (Fig. 2). After the regression model was fit to the data set, all pixels that fell below the regression mean curve and one positive standard deviation above the regression curve that had matched filtering scores of $0-1.2$ were classified as juniper presence. All other pixels were classified as juniper absence (Fig. 2). The standard deviation below the regression mean curve was not used as a threshold because no minimum threshold was necessary for the low infeasibility values. The selected maximum threshold for matched filtering scores was determined by iteratively testing for a threshold above zero to decide on juniper presence and absence and thereby optimize classification accuracy. To determine the appropriate threshold, the accuracies of multiple classification models were assessed with the digital color aerial orthophotograph, beginning with a nominal threshold value of 0.0 and incrementally increasing the threshold by 0.05 units until increases in threshold no longer improved accuracy.

The lidar point cloud data had a mean point density of 5.6 points $/ \mathrm{m}^{2}$ and vertical and horizontal accuracies of $10 \mathrm{~cm}$ and $30 \mathrm{~cm}$, respectively. The point cloud data were first subset to the three study areas and height-filtered to separate ground returns and vegetation returns using previously described methods and associated publically available lidar processing tools (Streutker and Glenn 2006; http://bcal.geology.isu.edu/ envitools/index.html). The point cloud data (Fig. 3A) were then converted into a raster format to generate maximum vegetation height maps (Fig. 3B) in two different spatial resolutions: 3-m and $30-\mathrm{m}$ raster cell size. A binary maximum vegetation height map (Fig. 3C) was then produced from each raster image (3-m and $30-\mathrm{m}$ resolutions) with the use of a 3-m height threshold. In the binary map, all pixels having maximum vegetation height of $>3 \mathrm{~m}$ were classified as juniper presence, and all other pixels were classified as juniper absence. This height threshold was chosen to separate juniper trees from shrubs best, as we encountered many big sagebrush and bitterbrush over $2 \mathrm{~m}$ in height at RCEW. Pratt et al. (2002) also indicate that big sagebrush and bitterbrush can grow up to $3 \mathrm{~m}$ in height. The two binary maps with 3-m and 30-m resolutions served two different purposes. The 3-m-resolution binary map was used to classify juniper canopy percent cover within $30 \times 30 \mathrm{~m}$ cells. A grid of $30 \times 30 \mathrm{~m}$ cells of each study area was overlaid on the $3-\mathrm{m}-$ resolution binary height map and the number and percent of the 3-m pixels classified as having juniper presence within each $30 \times 30-\mathrm{m}$ cell was calculated to estimate juniper canopy percent cover. The 30-m-resolution binary map was fused with the Landsat 5 TM-derived binary image of juniper presence/ absence to produce a final juniper presence/absence map (Fig. 4). All pixels that were classified as juniper presence in either Landsat 5 TM or lidar map were classified as juniper presence, whereas all other pixels were classified as juniper absence.

\section{Accuracy Assessment}

First, the lidar-derived juniper heights were assessed with the use of a simple linear regression model of the lidar-derived and fieldbased estimates of juniper tree heights. The lidar-derived estimates of juniper canopy percent cover in the $30 \times 30 \mathrm{~m}$ cells were assessed via a simple linear regression of the lidar-derived and field-based canopy-cover estimates (SPSS 14.0 for Windows). Then, the binary classifications of juniper presence and absence were assessed using the field plot data. The lidar-based classification accuracy was assessed with the use of the plots with juniper absence $(N=32)$ and the plots with junipers $>3 \mathrm{~m}$ tall $(N=58)$ because of the $3-\mathrm{m}$ height threshold that was set to exclude tall shrubs. The Landsat 5 TM-based classification accuracy was first assessed with the use of all 100 plots. Then, a separate accuracy assessment was performed with the use of only the plots with junipers $<3 \mathrm{~m}$ tall $(N=10)$ and plots with juniper absence $(N=32)$. It was particularly important to determine if the Landsat $5 \mathrm{TM}$-based classification offered a complementary advantage to lidar by detecting juniper seedlings, which were widespread across our study areas, but were excluded by the lidar-based classification. The fusion-based classification accuracy assessment included all field plots $(N=100)$.

\section{Change Detection}

Two separate change detections were performed. First, a simple image differencing method, which is a pixel-by-pixel comparison (Lillesand and Kiefer 2000) was used to compare the 1965 juniper map with the 2008 fusion-based juniper presence/ 


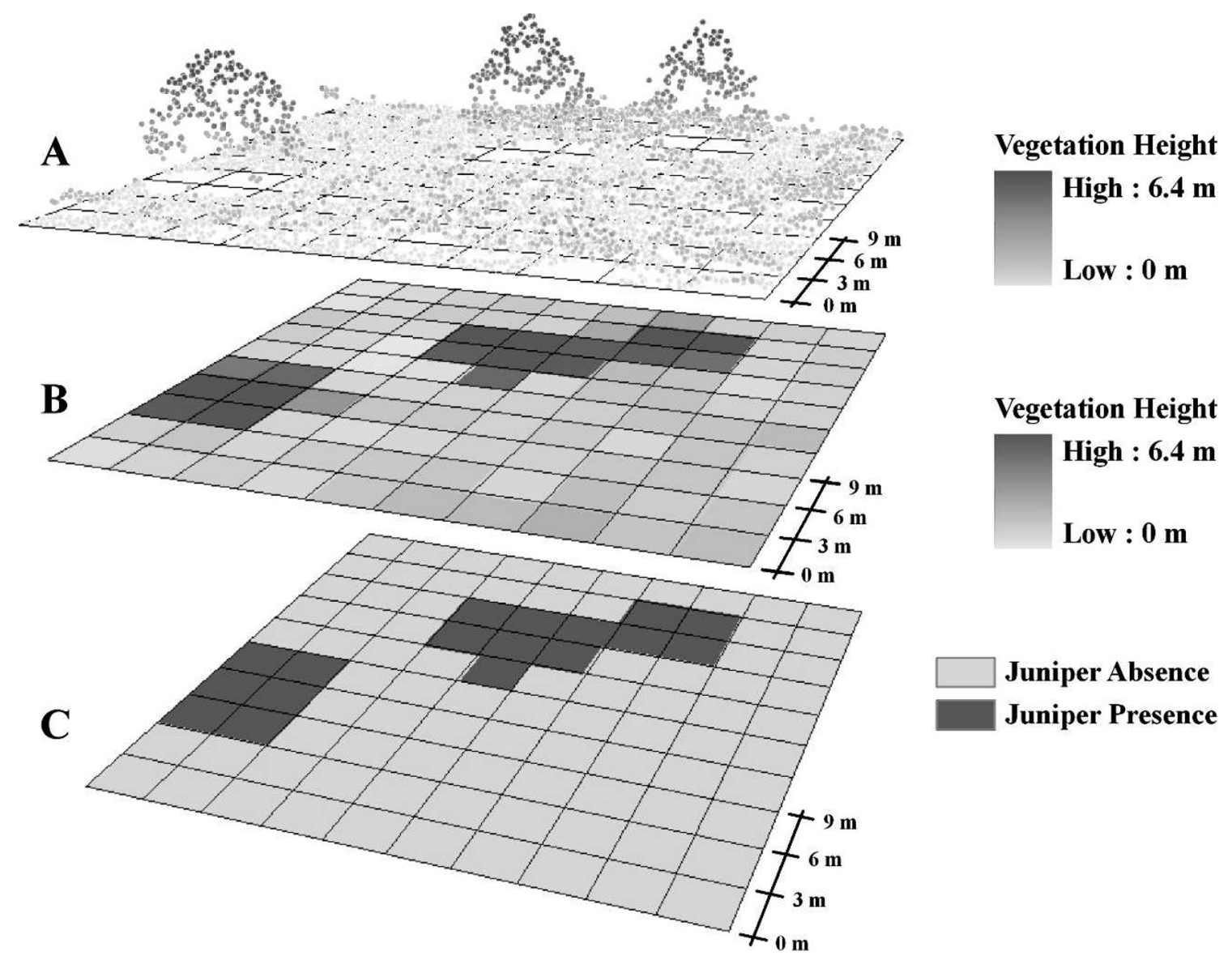

Figure 3. Lidar-based classification of juniper presence and absence in a $30 \times 30 \mathrm{~m}$ cell. Lidar point cloud data (A) are first rasterized to classify maximum vegetation heights in 3-m pixels (B). The maximum vegetation heights are then classified with a 3-m height threshold to produce a binary juniper presence and absence classification (C). The binary map is used to estimate juniper canopy percent cover within $30 \times 30-\mathrm{m}$ cells, an area equal to one pixel in a Landsat 5 Thematic Mapper image.

absence map and detect pixels with newly established junipers, where junipers were absent in 1965. This allowed us to examine juniper expansion across the study areas over the 43yr period. Second, we compared the estimates of juniper canopy percent cover from the two time periods to examine juniper-density changes over the 43-yr period within the 1965 juniper distribution boundary. Each of the 1965 juniper polygons included an ocular estimate of total vegetation cover, which included both the juniper and shrub canopy. These estimates assigned one of four possible cover classes to each polygon: $1-25 \%, 26-50 \%, 51-75 \%$, and $76-100 \%$. To derive a similar estimate for 2008 , we estimated total juniper canopy percent cover for each polygon by determining the total number and percent of 3-m lidar pixels classified as juniper within each area of the 1965 juniper distribution. This estimate was then compared to the total canopy cover in 1965 to determine if juniper canopy cover alone in 2008 had reached or exceeded the upper limit of the estimated range from 1965.

\section{Land-Cover Type Map}

An independent variable of land-cover types was created with the use of the 1965 digital vegetation cover map and GIS. This map included five different vegetation associations within the three study areas: mountain big sagebrush (Artemisia tridentata Nutt. subsp. vaseyana [Rydb.] Beetle)/bluebunch wheatgrass
(Pseudoroegneria spicata [Pursh] A. Löve subsp. spicata), mountain big sagebrush/bitterbrush (Purshia tridentata [Pursh] DC), mountain big sagebrush/snowberry (Symphoricarpos oreophis Gray), low sagebrush (Artemisia arbuscula Nutt.)/ bluebunch wheatgrass, and low sagebrush/Idaho fescue (Festuca idahoensis Elmer). Juniper expansion and current juniper canopy cover were analyzed separately with these land-cover types. First, total areas of juniper increase from 1965 to 2008 were estimated within each polygon of each land-cover type ( $N=26$ polygons). To determine if juniper expansion rates varied with land-cover types, these estimates were compared among the five vegetation associations with the use of an analysis of variance (ANOVA) test with all pairwise post hoc comparisons (SPSS 14.0 for Windows). Second, the estimates of current juniper canopy percent cover within the $30 \times 30 \mathrm{~m}$ cells were compared among the five vegetation associations with the use of an ANOVA test with all pairwise post hoc comparisons to determine if juniper canopy cover varied with land-cover types ( $N=2896$ cells; SPSS 14.0 for Windows).

\section{RESULTS}

\section{Field Measurements}

A total of 745 juniper stems were mapped in the 100 plots. Of these, 442 were classified as mature trees and 303 as seedlings. 

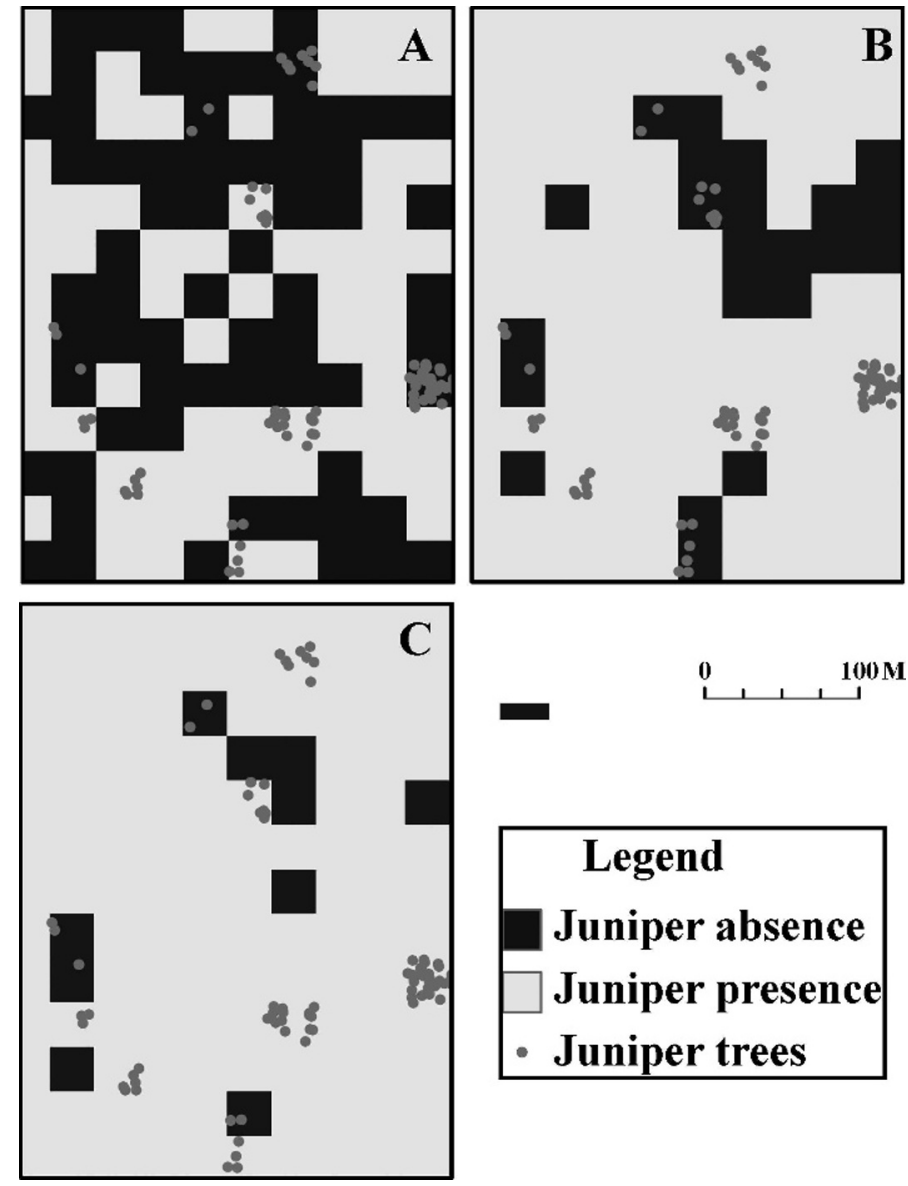

Figure 4. Fusion-based classification of juniper presence and absence. Landsat 5 Thematic Mapper (TM) image (A) and lidar data (B) are first individually classified to detect juniper presence. The two classifications are then fused to produce a final binary map (C). All pixels that were classified as juniper presence in either the Landsat 5 TM or lidar image were classified as juniper presence in the fusion model, and all other pixels were classified as juniper absence. The fusion-based classification accuracy was assessed with the use of field-based global positioning system maps of individual juniper trees (circles). In this example, 89 trees out of 96 juniper trees are correctly classified as juniper presence, and seven trees are wrongly classified as juniper absence.

A tree-height class distribution indicated that $59 \%$ of the total juniper were in the $>3-\mathrm{m}$ height class and $41 \%$ in the $<3-\mathrm{m}$ height class. Mean juniper stem density was 92 stems/ha. Mean mature tree height was $4.6 \mathrm{~m}$ and mean mature tree age was 60 yr (Fig. 5). Mean seedling height was $1.5 \mathrm{~m}$ and mean seedling age was $30 \mathrm{yr}$. Juniper tree age and height were significantly correlated ( $P<0.001$, Adj. $R^{2}=0.60$; Fig. 6).

\section{Image Classification}

Lidar-derived juniper tree heights were significantly correlated with the field-based measurements of juniper tree heights $\left(P<0.0001\right.$, Adj. $R^{2}=0.80$; Fig. 7). Lidar-derived estimates of juniper canopy cover were also significantly correlated with the field-based juniper canopy measurements $\left(P<0.001, \mathrm{Adj} . R^{2}\right.$ $=0.69)$. Lidar-derived estimates of juniper canopy percent cover were $17 \%, 17 \%$, and $39 \%$ in study areas 1,2 , and 3 , respectively. The remaining $83 \%, 83 \%$, and $61 \%$ of these

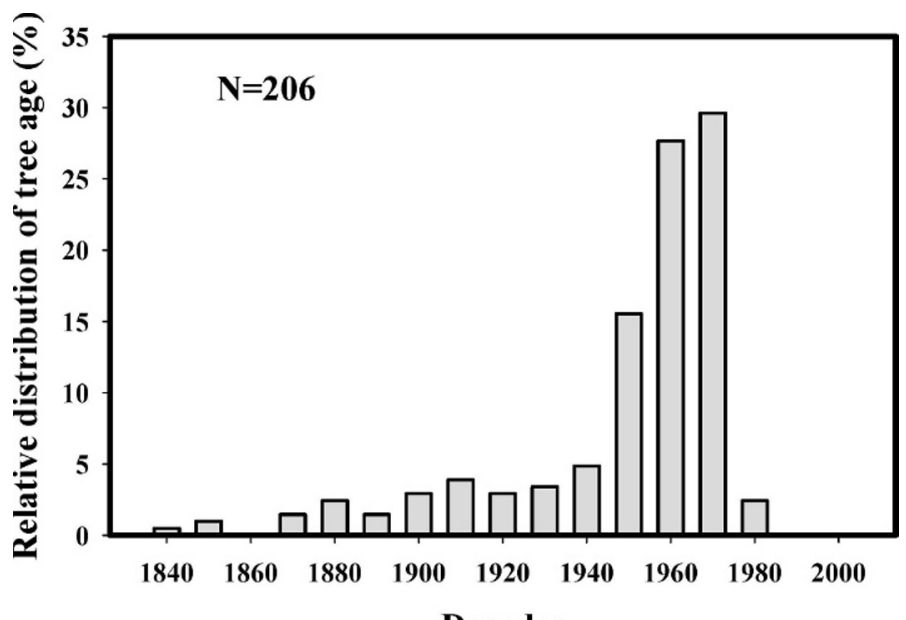

Decades

Figure 5. Juniper tree-age distribution from the Reynolds Creek watershed at a decadal scale.

study areas were composed of vegetation $<3 \mathrm{~m}$ tall, including shrubs and juvenile junipers $<3 \mathrm{~m}$ tall. The lidar-based classification of $>3$-m-tall juniper presence and absence had an overall accuracy of $94 \%$ (Table 2 ). The producer's and user's accuracies for juniper presence were $91 \%$ and $100 \%$, respectively, whereas producer's and user's accuracies for juniper absence were $100 \%$ and $86 \%$, respectively. The Landsat 5 TM MTMF bands of matched filtering scores and infeasibility values were successfully combined. The quadratic regression model indicated a statistically significant relationship between the two bands ( $P$ value $\left.<0.0001, R^{2}=0.52\right)$. The resulting Landsat 5 TM-based classification of juniper (all heights) presence and absence had $68 \%$ overall accuracy. The producer's and user's accuracies for juniper presence were $65 \%$ and $85 \%$, respectively, and the producer's and user's accuracies for juniper absence were $75 \%$ and $50 \%$, respectively (not presented in a table). When a separate accuracy assessment was performed for the Landsat 5 TM-based classification of junipers $<3 \mathrm{~m}$ tall (Table 3 ), the classification had an overall accuracy of $71 \%$. The producer's and user's accuracies for

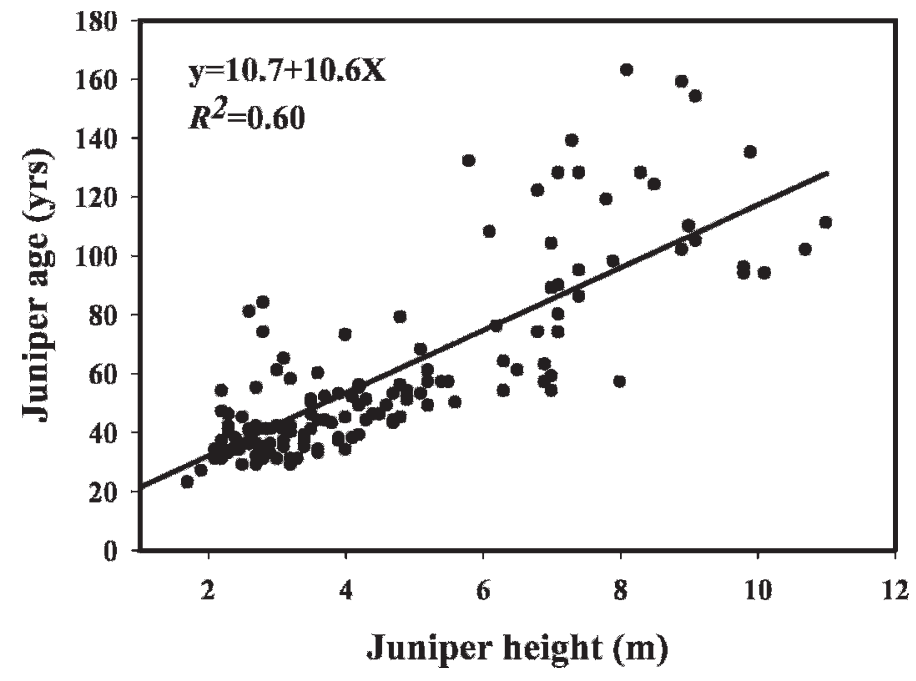

Figure $\mathbf{6}$. The relationship between mature juniper tree age and juniper tree height at the Reynolds Creek watershed. 


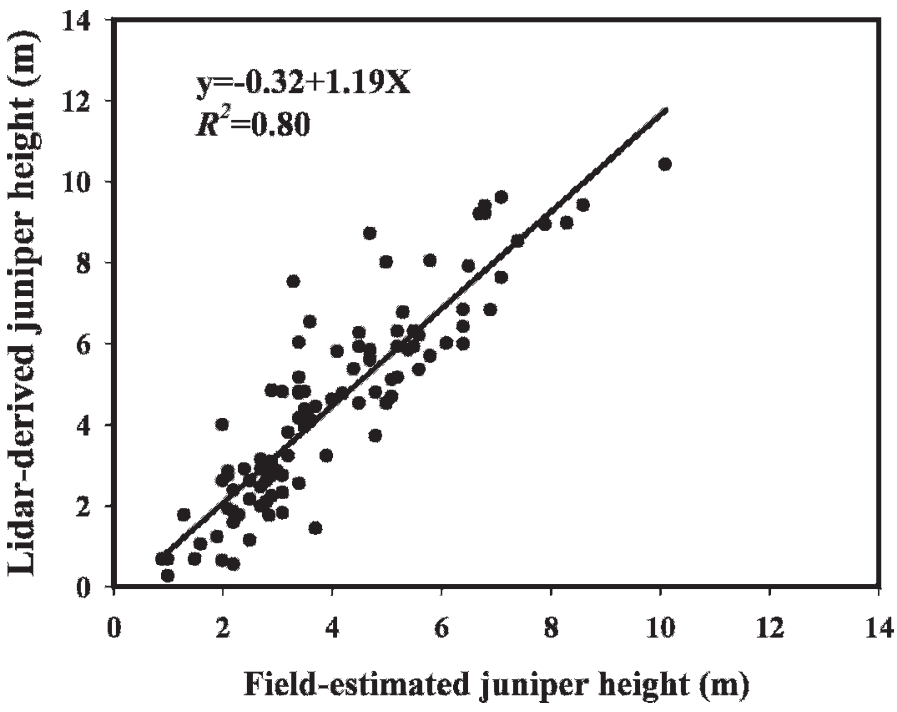

Figure 7. The relationship between lidar-derived and field-estimated juniper tree height.

juniper presence were $60 \%$ and $43 \%$, respectively, and the producer's and user's accuracies for juniper absence were $75 \%$ and $86 \%$, respectively. The Landsat 5 TM-based classification detected $60 \%$ of the junipers $<3 \mathrm{~m}$ tall, which were not identified with the lidar-based classification. The fusion-based classification had $83 \%$ overall accuracy. Its producer's and user's accuracies for juniper presence were both $88 \%$, and its producer's and user's accuracies for juniper absence were $75 \%$ and $73 \%$ (Table 4$)$. The fusion-based classification was chosen as the best model in this landscape and used for juniper change detection, as this binary classification included both mature and juvenile junipers.

\section{Juniper Change Detection}

Only $9.6 \%$ of the three combined study areas were classified as having junipers in 1965 , whereas $94.6 \%$ of the combined areas were classified as having junipers in 2008. Pixel-by-pixel comparison indicated juniper expansion of $85 \%$. Study areas 1 and 2 were classified in 1965 as having 26-50\% total cover of sagebrush and juniper combined. In 2008, however, total juniper cover alone covered $53 \%$ and $45 \%$ of study areas 1 and 2 , respectively. Study area 3 was classified in 1965 as having $51-75 \%$ total sagebrush and juniper cover combined. The 2008 estimate of total juniper canopy cover alone in this area was $44 \%$.

Table 2. Lidar-based classification of junipers $>3 \mathrm{~m}$ tall.

\begin{tabular}{|c|c|c|c|c|}
\hline \multirow[b]{2}{*}{ Classification data } & \multicolumn{2}{|c|}{ Field data } & \multirow[b]{2}{*}{$\begin{array}{l}\text { Row } \\
\text { total }\end{array}$} & \multirow[b]{2}{*}{$\begin{array}{c}\text { User's } \\
\text { accuracy }\end{array}$} \\
\hline & $\begin{array}{l}\text { Juniper } \\
\text { presence } \\
(N=58)\end{array}$ & $\begin{array}{l}\text { Juniper } \\
\text { absence } \\
(N=32)\end{array}$ & & \\
\hline Juniper presence & 53 & 0 & 53 & $100 \%$ \\
\hline Juniper absence & 5 & 32 & 37 & $86 \%$ \\
\hline Column total & 53 & 32 & & \\
\hline Producer's accuracy & $91 \%$ & $100 \%$ & & \\
\hline Overall accuracy & $94 \%$ & & & \\
\hline
\end{tabular}

Table 3. Landsat 5 Thematic Mapper-based classification of junipers $<3 \mathrm{~m}$ tall.

\begin{tabular}{lcccc}
\hline & \multicolumn{2}{c}{ Field data } & & \\
\cline { 2 - 4 } & $\begin{array}{c}\text { Juniper } \\
\text { presence } \\
(N=10)\end{array}$ & $\begin{array}{c}\text { Juniper } \\
\text { absence } \\
\text { Classification data }\end{array}$ & Row & User's \\
& $(N=32)$ & & total & accuracy \\
\hline Juniper presence & 6 & 8 & 64 & $43 \%$ \\
Juniper absence & 4 & 24 & 36 & $86 \%$ \\
Column total & 10 & 32 & & \\
Producer's accuracy & $60 \%$ & $75 \%$ & & \\
Overall accuracy & $71 \%$ & & & \\
\hline
\end{tabular}

To corroborate the image-based estimate of juniper change, juniper tree-age distribution was constructed at a decadal scale. The tree-age distribution indicated that $60 \%$ of the mature trees sampled were new trees that established since the decade from 1960 to 1970 (Fig. 5). This age distribution does not include stems that were classified as seedlings. Approximately $41 \%$ of the stems mapped in the field were classified as seedlings. The seedling-age distribution indicated that $91 \%$ of these stems were additional junipers that established since the decade from 1960 to 1970.

Juniper expansion rates did not vary significantly among land-cover types $(P=0.606, N=26$ polygons), but juniper canopy cover did $(P<0.001, N=2896$ cells). The pairwise post hoc comparisons indicated significantly different juniper canopy cover in all possible pairs (all $P$ values $<0.001$; Fig. 8). Mountain big sagebrush/bitterbrush association had the lowest juniper canopy cover, whereas the low sagebrush/Idaho fescue association had the greatest juniper canopy cover.

\section{DISCUSSION}

\section{Juniper Encroachment}

Western juniper is increasing in both extent and density at the Reynolds Creek Experimental Watershed in southwestern Idaho. The change detection results demonstrate that the aerial extent of western juniper has increased $85 \%$ within the area examined since 1965, indicating an encroachment rate of approximately $2 \%$ per year. This estimate is comparable to a previous satellite-image-based estimate of juniper encroachment rate of up to $1.5 \%$ per year in southeastern Idaho (Sankey and Germino), but lower than the Strand et al. (2006) estimate of a $4.5 \%$ encroachment rate derived from analysis of aerial photographs at a site near the RCEW. The estimated

Table 4. Fusion-based juniper classification accuracy.

\begin{tabular}{lcccc}
\hline & \multicolumn{2}{c}{ Field data } & & \\
\cline { 2 - 3 } & $\begin{array}{c}\text { Juniper } \\
\text { presence } \\
(N=68)\end{array}$ & $\begin{array}{c}\text { Juniper } \\
\text { absence } \\
(N=32)\end{array}$ & Row & User's \\
Classification data & 59 & 8 & 67 & accuracy \\
\hline Juniper presence & 9 & 24 & 33 & $73 \%$ \\
Juniper absence & 68 & 32 & & \\
Column total & $88 \%$ & $75 \%$ & & \\
Producer's accuracy & $83 \%$ & & & \\
Overall accuracy & & & & \\
\hline
\end{tabular}




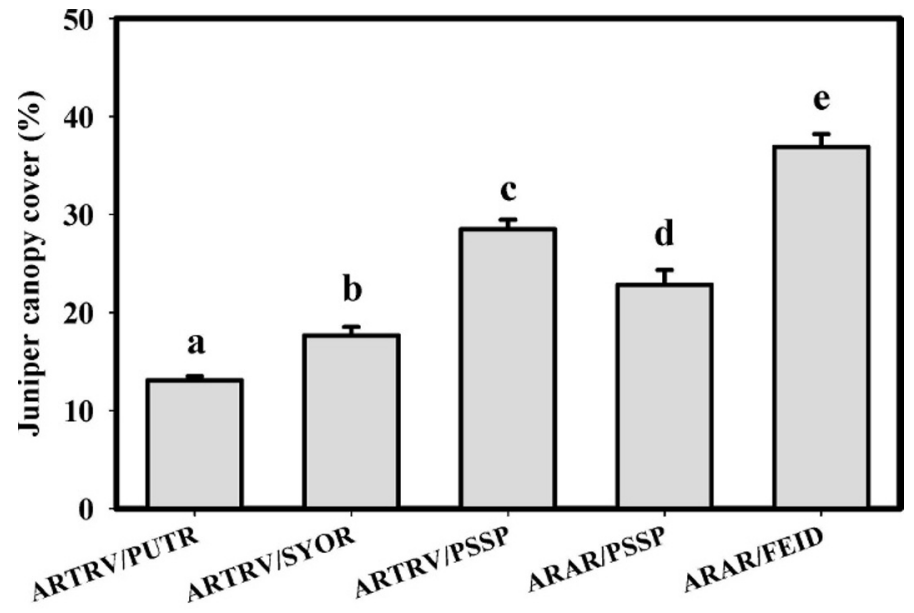

Vegetation associations

Figure 8. Juniper canopy percent cover at the five different resident vegetation associations: mountain big sagebrush/bitterbrush (ARTRV/ PUTR), mountain big sagebrush/snowberry (ARTRV/SYOR), mountain big sagebrush/bluebunch wheatgrass (ARTRV/PSSP), low sagebrush/ bluebunch wheatgrass (ARAR/PSSP), and low sagebrush/ldaho fescue (ARAR/FEID). Juniper canopy percent cover significantly varied among all associations (all $P$ values $<0.05$ ).

encroachment rate at the RCEW is also within the $1-4.2 \%$ range estimated from field-based measurements in other areas of the Great Basin, where the areal extent of juniper has seen a 150-625\% increase since 1860 (Romme et al. 2009). A juniper-density increase was indicated at two of the three study areas by juniper canopy-cover estimates that reached or exceeded the total canopy-cover range estimated in 1965. Previously reported rates of juniper-density increase have been $10 \%$ per decade (Weisberg et al. 2007) with a doubling of tree density every $30 \mathrm{yr}$ (Romme et al. 2009). Extensive infill of old stands has also been documented in Nevada, Colorado, New Mexico, and Arizona, even in exposed, dry sites (Romme et al. 2009).

The tree-ring data support the image-based estimate of juniper encroachment rate. Consistent with the changedetection results, the combined seedling- and mature tree-age distribution indicated that a vast majority of junipers at the RCEW established over the last 40-50 yr. This pattern is similar to juniper-age distributions constructed by Miller and Rose (1995), Tausch and West (1988), and Tausch et al. (1981), which all indicate increased juniper establishment in the Great Basin, in some cases at an exponential rate, since the mid-20th century. Over $90 \%$ of the western juniper woodlands, which occupy 3.2 million ha in the intermountain West, have been estimated to be less than $100 \mathrm{yr}$ of age (Miller and Wigand 1994; Miller et al. 2000). The estimated mean mature tree age at the RCEW was $60 \mathrm{yr}$, which might have important implications for juniper encroachment in the coming decades. Johnson and Miller (2006) indicate that western juniper encroachment rates increase as trees reach maximal reproductive maturity at 50-70 yr of age (Miller and Rose 1995).

Juniper canopy cover significantly varied among the landcover types (Fig. 8). The mountain big sagebrush/bluebunch wheatgrass association had significantly greater juniper canopy cover compared to the mountain big sagebrush/snowberry and mountain big sagebrush/bitterbrush associations. This has important implications for prioritizing juniper management in the watershed. A previous study documented that both herbaceous and mountain big sagebrush cover significantly declined, and bare-ground cover significantly increased with increasing juniper canopy cover in mountain big sagebrush/ Thurber needlegrass/bluebunch wheatgrass associations (Miller et al. 2000). When juniper canopy cover reached $50 \%$ of maximum juniper cover, perennial herbaceous vegetation drastically declined to only $6 \%$ cover. In comparison, increasing juniper canopy cover has been documented to have little effect on snowberry and varying effects on bitterbrush in mountain big sagebrush-dominated communities (Miller et al. 2000). Mountain big sagebrush/bitterbrush and mountain big sagebrush/snowberry associations at Reynolds Creek watershed currently have the lowest juniper canopy cover. In contrast, the low sagebrush-dominated communities had the greatest juniper canopy cover. This might be due to the greater initial juniper canopy cover in 1965 in the low sagebrush communities, because infill is a density-dependent process (Weisberg et al. 2007). Furthermore, a previous study documented that both low sagebrush and co-occurring herbaceous cover were not significantly affected by increasing juniper canopy cover in low sagebrush/Sandberg bluegrass/Idaho fescue associations (Miller et al. 2000).

\section{Juniper Classification}

The lidar-based binary classification of juniper presence and absence performed well and had the best accuracies of all three binary classifications. It detected individual juniper trees even at very low percent cover of canopy. However, the lidar-based classification excluded short junipers even at locations of high juniper density and canopy cover. This is because of the 3-m height threshold, which was set to exclude the large presence of tall shrubs. The Landsat 5 TM-based classification had the lowest accuracies, but it successfully detected the short junipers at high density. Indeed, $60 \%$ of the short junipers that were not detected by the lidar-based classification were successfully detected by the Landsat 5 TM-based classification. The fusionbased juniper classification performed better than both of the individual classifications in this landscape, especially from a management perspective. The performance is largely due to the complimentary characteristics of the two distinct data types. Although the lidar-based classification successfully detected sparsely distributed mature juniper trees at low canopy percent cover, the Landsat 5 TM-based classification detected many of the juvenile junipers. Fused together, the lidar and Landsat 5 TM data accurately classified most juniper trees. Compared to the lidar-based classification alone, the fusion-based classification resulted in increased false positives, which led to decreased accuracies, particularly for juniper absence. However, the improved detection of the presence of juvenile junipers is the key advantage of the fusion, especially considering that up to $83 \%$ of our study areas had mixed vegetation of shrubs and junipers $<3 \mathrm{~m}$ tall. The juvenile junipers $<3 \mathrm{~m}$ tall across these large areas also comprised $41 \%$ of all junipers mapped at the RCEW. Land managers interested in early detection of encroaching juvenile junipers as a management priority might 


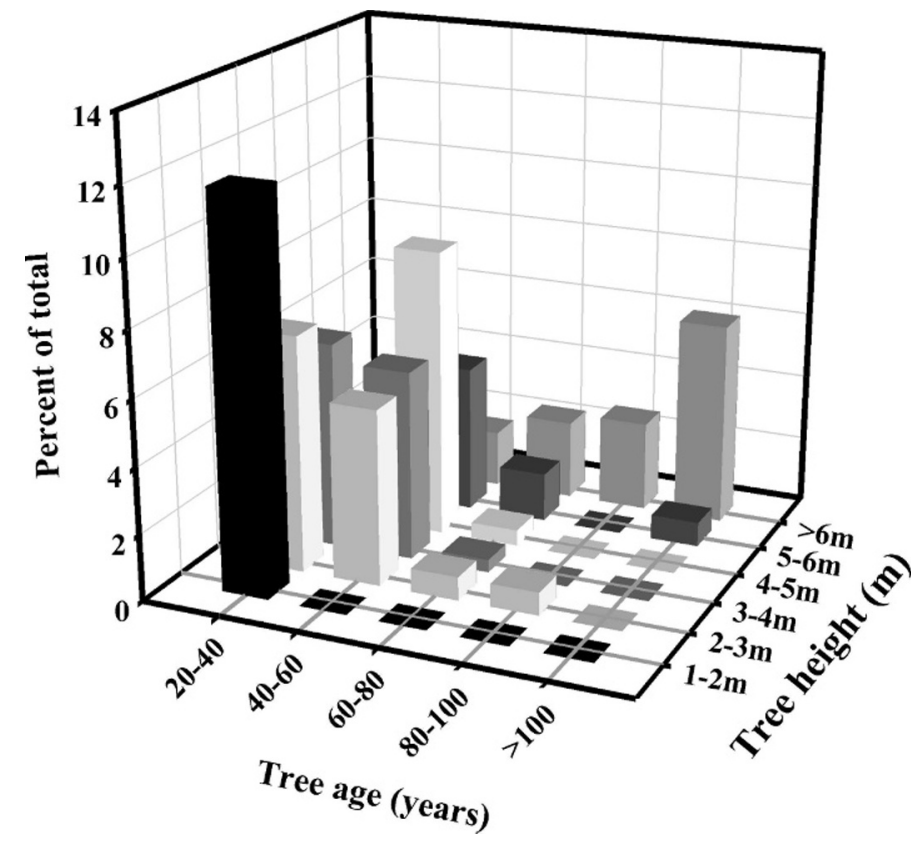

Figure 9. Lidar-derived juniper tree-height classes and predicted juniper-age distribution within each height class at a small subset of our study areas ( $N=87476$ pixels with 3-m resolution).

find the fusion model more useful. However, lidar data alone might be sufficient for mapping mature junipers, especially in areas where juvenile junipers do not comprise a large portion of the community. Lidar data alone might also be used in areas without shrubs mixed with junipers. Furthermore, future studies at sites without tall shrubs could use a height threshold lower than $3 \mathrm{~m}$ to improve the detection of juvenile junipers. In addition, lidar point cloud data might be used to separate juniper seedlings and shrubs based on three-dimensional plant shape descriptions.

The lidar-derived juniper heights were strongly correlated with field-based tree-height measurements. This correlation would be expected to be greater for sparsely distributed junipers in low-statured vegetation communities where the encroachment is in its early phases and juniper canopies do not overlap. Juniper tree heights were also significantly correlated with juniper tree age, and explained $60 \%$ of the variability. Taken together, these results suggest that the height of individual junipers or juniper stands in encroached areas can be estimated by lidar data, which might then be used to derive juniper-age distribution. We provide an example of this application at a small subset of our study areas (Fig. 9). In this example, we estimate maximum vegetation heights in $3-\mathrm{m}$ pixels across a juniper-encroached low sagebrush/Idaho fescue association. We then create maximum vegetation height classes (3-m pixels), each of which are then subdivided into juniper-age classes based on our tree-age distribution. In the low sagebrush/ Idaho fescue association example, maximum vegetation above $1 \mathrm{~m}$ is assumed to be juniper, and maximum vegetation heights below this threshold, which made up $31 \%$ of the total distribution, are not classified, because this height class includes both juniper and shrubs. Similar to this application, lidar-derived juniper tree heights might be used to derive juniper tree biomass, carbon storage (Strand et al. 2006), density, and canopy volume, due to height relationships with these and other physical characteristics (Wulder et al. 2007). The example provided here used rasterized lidar data with a user-defined pixel size. Similar user-defined height classifications can be performed with the use of lidar point cloud data (http://bcal.geology.isu.edu/envitools/index.html).

\section{MANAGEMENT IMPLICATIONS}

This study demonstrated a successful application of lidar data and its fusion with Landsat 5 TM image in accurately classifying juniper and characterizing juniper encroachment into rangelands. This application can be used over large areas to estimate rapidly both juniper expansion and infill and to examine spatial patterns and rates of these processes. Lidarestimated juniper cover appears to vary within RCEW as a function of land-cover types. Such lidar-derived information can be used to prioritize intensive juniper management areas. Lidar-derived juniper height information might also be used to derive other physical characteristics of encroaching junipers.

\section{LITERATURE CITED}

Adams, J. B., M. O. Smith, ANd P. E. Johnson. 1986. Spectral mixture modeling: a new analysis of rock and soil types at the Viking Lander 1 site. Journal of Geophysical Research 91:8098-8112.

Boardman, J. W. 1998. Leveraging the high dimensionality of AVIRIS data for improved sub-pixel target unmixing and rejection of false positives: mixture tuned matched filtering. AVIRIS 1998 Proceedings. Pasadena City, CA, USA: JPL. 6 p.

BoRk, E. W., AND J. G. Su. 2007. Integrating LiDAR data and multispectral imagery for enhanced classification of rangeland vegetation: a meta analysis. Remote Sensing of Environment 111:11-24

Chen, X., L. Vierling, E. Rowell, and T. DeFelice. 2004. Using lidar and effective LAI data to evaluate IKONOS and Landsat 7 ETM+ vegetation cover estimates in a ponderosa pine forest. Remote Sensing of Environment 91:14-26.

Hanson, C. L. 2001. Long-term precipitation database, Reynolds Creek Experimental Watershed, Idaho, United States. Water Resources Research 37:2831-2834.

Hanson, C. L., D. Marks, and S. S. Van Vactor. 2001. Long-term climate database, Reynolds Creek Experimental Watershed, Idaho, United States. Water Resources Research 37:2839-2841.

Johnson, D., and R. F. Miller. 2006. Structure and development of expanding western juniper woodlands as influenced by two topographic variables. Forest Ecology and Management 229:7-15.

LillesAnd, T. M., AND R. W. KiefER. 2000. Remote sensing and image interpretation. 4th ed. New York, NY, USA: Wiley. $568 \mathrm{p}$.

Marks, D., K. R. Cooley, D. C. Robertson, and A. Winstral. 2001. Long-term snow database, Reynolds Creek Experimental Watershed, Idaho, United States. Water Resources Research 37:2835-2838.

MilleR, R. F., AND J. A. Rose. 1995. Historic expansion of Juniperus occidentalis (western juniper) in southeastern Oregon. Great Basin Naturalist 55:37-45.

Miller, R. F., T. J. Svejcar, and J. A. Rose. 2000. Impacts of western juniper on plant community composition and structure. Journal of Range Management 53:574-585

Miller, R. F., and P. E. Wigand. 1994. Holocene changes in semiarid pinyonjuniper woodlands. Bioscience 44:465-473.

MITCHELL, J., AND N. F. GLenN. 2009. Matched filtering subpixel abundance estimates in mixture-tuned matched filtering classifications of leafy spurge (Euphorbia esula L.). International Journal of Remote Sensing 30:1-21. 
Mundt, J. T., D. R. Streutker, and N. F. Glenn. 2006. Mapping sagebrush distribution using fusion of hyperspectral and Lidar classifications. Photogrammetric Engineering and Remote Sensing 72:47-54.

Pierson, F. B., C. W. Slaughter, and Z. K. Cram. 2001. Long-term stream discharge and suspended-sediment database, Reynolds Creek Experimental Watershed, Idaho, United States. Water Resources Research 37:2857-2861.

Pratt, M., J. Browns, R. Banner, and A. Rasmussen. 2002. Range plants of Utah. Utah State University Extension. Available at: http://extension.usu.edu/range/ index.htm. Accessed 15 July 2009.

Rango, A., M. J. Chopping, J. C. Ritchie, K. Havstad, W. Kustas, and T. Schmugge. 2000. Morphological characteristics of shrub coppice dunes in desert grasslands of southern New Mexico derived from scanning LiDAR. Remote Sensing of Environment 76:26-44.

Riaño, D., E. Chuvieco, S. L. Ustin, J. Salas, J. R. Rodriguez-Perez, L. M. Ribeiro, D. X. Viegas, J. M. Moreno, and H. Fernandez. 2007. Estimation of shrub height for fuel-type mapping combining airborne LiDAR and simultaneous color infrared ortho imaging. International Journal of Wildland Fire 16:341-348.

Ritchie, J. C., K. S. Humes, And M. A. Weltz. 1995. Laser altimeter measurements at Walnut Gulch watershed, Arizona. Journal of Soil and Water Conservation 50:440-442.

Romme, W. H., C. A. Allen, J. D. Bailey, W. L. Baker, B. T. Bestelmeyer, P. M. Brown, K. S. Elsenhart, M. L. Floyd, D. W. Huffman, B. F. Jacobs, R. F. Miller, E. H. Muldavin, T. W. Swetnam, R. J. Tausch, and P. J. Weisberg. 2009. Historical and modern disturbance regimes, stand structures, and landscape dynamics in pinon-juniper vegetation of the western United States. Rangeland Ecology and Management 62:203-222.

Sankey, T. T., And M. J. Germino. 2008. Assessment of juniper encroachment with the use of satellite imagery and geospatial data. Rangeland Ecology and Management 61:412-418.

Sankey, T. T., C. Montagne, L. Graumlich, R. Lawrence, and J. Nielsen. 2006. Twentieth century forest-grassland ecotone shift in Montana under differing livestock grazing pressure. Forest Ecology and Management 234:282292.

Seyfried, M. S., G. N. Flerchinger, M. D. Murdock, C. L. Hanson, and S. Van Vactor. 2001a. Long-term soil temperature database, Reynolds Creek Experimental Watershed, Idaho, United States. Water Resources Research 37:2843-2846

Seyfried, M. S., C. L. Hanson, M. D. Murdock, and S. Van Vactor. 2001b. Long-term lysimeter database, Reynolds Creek Experimental Watershed, Idaho, United States. Water Resources Research 37:2853-2856.

Seyfried, M., R. Harris, D. Marks, and B. Jacob. 2001c. Geographic database, Reynolds Creek Experimental Watershed, Idaho, United States. Water Resources Research 37:2825-2829.

Seyfried, M. S., M. D. Murdock, C. L. Hanson, G. N. Flerchinger, and S. Van Vactor. 2001d. Long-term soil water content database, Reynolds Creek Experimental Watershed, Idaho, United States. Water Resources Research 37:2847-2851.
Singh, N., and N. Glenn. 2009. Multitemporal spectral analysis for cheatgrass (Bromus tectorum) classification. International Journal of Remote Sensing 30:3441-3462.

Slaughter, C. W., D. Marks, G. N. Flerchinger, S. S. Van Vactor, and M. Burgess. 2001. Thirty-five years of research data collection at the Reynolds Creek Experimental Watershed, Idaho, United States. Water Resources Research 37:2819-2823.

SMALL, C. 2004. The Landsat ETM+ spectral mixing space. Remote Sensing of Environment 93:1-17.

Small, C., AND J. W. T. Lu. 2006. Estimation and vicarious validation of urban vegetation abundance by spectral mixture analysis. Remote Sensing of Environment 100:441-456.

Stokes, M. A., And T. L. Smiley. 1968. An introduction to tree-ring dating. Tucson, AZ, USA: The University of Arizona Press. 73 p.

Strand, E. K., A. M. S. Smith, S. C. Bunting, L. A. Vierling, D. B. Hann, and P. E. Gessler. 2006. Wavelet estimation of plant spatial patterns in multitemporal aerial photography. International Journal of Remote Sensing 27:2049-2054.

Streutker, D. R., and N. F. Glenn. 2006. LiDAR measurement of sagebrush steppe vegetation heights. Remote Sensing of Environment 102:135-145.

Su, J. G., AND E. W. Bork. 2007. Characterization of diverse plant communities in Aspen Parkland rangeland using LiDAR data. Applied Vegetation Science 10:407-416.

Tausch, R. J., And N. E. West. 1988. Differential establishment of pinyon and juniper following fire. The American Midland Naturalist 119:174-184.

Tausch, R. J., N. E. West, and A. A. Nabi. 1981. Tree age and dominance patterns in Great Basin pinyon-juniper woodlands. Journal of Range Management 34:259-264.

uSDA national Agricultural Imagery Program Imagery. 2009. Idaho USDA NAIP 2004 digital orthoimage collection. Available at: http://maps.insideidaho.org/ WebMapping/Search/DownloadNAIP. Accessed 1 May 2009.

Waichler, W. S., R. Miller, and P. S. Doescher. 2001. Community characteristics of old-growth western juniper woodlands. Journal of Range Management 54:518-527.

Weisberg, P. J., E. Lingua, and R. B. Pillai. 2007. Spatial patterns of pinyon-juniper woodland expansion in central Nevada. Journal of Range Management 60:115-124.

Weltz, M. A., J. C. Ritchie, and H. D. Fox. 1994. Comparison of laser and field measurements of vegetation height and canopy cover. Water Resources Research 30:1311-1319.

Wulder, M. A., T. Han, J. C. White, T. SWeda, and H. Tsuzuki. 2007. Integrating profiling LIDAR with Landsat data for regional boreal forest canopy attribute estimation and change characterization. Remote Sensing of Environment 110:123-137.

XIAO, J., AND A. Moody. 2005. A comparison of methods for estimating fractional green vegetation cover within a desert-to-upland transition zone in central New Mexico, USA. Remote Sensing of Environment 98:237-250. 